\title{
Livelihood diversification and welfare of rural households in Ondo State, Nigeria
}

\author{
Adepoju Abimbola O.* and Obayelu Oluwakemi A. \\ Department of Agricultural Economics, University of Ibadan, Oyo State, Nigeria. \\ Accepted 10 September, 2013.
}

\begin{abstract}
Agriculture, the main source of livelihood in Nigeria, especially in the rural areas, is plagued with various problems. As a result, most of the rural households are poor and are beginning to diversify their livelihoods into off and non-farm activities as a relevant source of income. This study examined the effect of livelihood diversification on the welfare of rural households in Ondo State. Primary data used in the study were obtained from 143 respondents selected employing a multistage sampling technique. Data were analyzed using descriptive statistics, multinomial logit and the logit regression models. The distribution of respondents by the type of livelihood strategy adopted revealed that almost three-quarters of the respondents adopted the combination of farm and nonfarm strategy. Econometric analysis showed that household size, total household income and primary education of the household head were the dominant factors influencing the choice of livelihood strategies adopted. Income from non-farm activities, as well as income from a combination of non-farm and farming activities, impacted welfare positively relative to income from farming activities. The study recommends the promotion of non-farm employment as a good strategy for supplementing the income of farmers as well as sustaining equitable rural growth.
\end{abstract}

Key words: Ondo State, livelihood diversification, welfare, rural households, Nigeria.

\section{INTRODUCTION}

In Africa, various studies have shown that while most rural households are involved in agricultural activities such as livestock, crop or fish production as their main source of livelihood, they also engage in other income generating activities to augment their main source of income. A majority of rural producers have historically diversified their productive activities to encompass a range of other productive areas. In other words, very few of them collect all their income from only one source, hold all their wealth in the form of any single asset, or use their resources in just one activity (Barrett et al., 2001). In Nigeria, the agricultural sector is plagued with problems which include soil infertility, infrastructural inadequacy, risk and uncertainty and seasonality among others. Thus, rural households are forced to develop strategies to cope with increasing vulnerability associated with agricultural production through diversification, intensification and migration or moving out of farming (Ellis, 2000). In other words, the situation in the rural areas has negative welfare implications and predisposes the rural populace to various risks which threaten their livelihoods and their existence. As a result of this struggle to survive and in order to improve their welfare, off-farm and non-farm activities have become an important component of livelihood strategies among rural households in Nigeria. Further, the growing interest in research on rural off-farm and non-farm income in rural economies is increasingly showing that rural peoples' livelihoods are derived from 
diverse sources and are not as overwhelmingly dependent on agriculture as previously assumed (Gordon and Craig, 2001). This could be owing to the fact that a diversified livelihood, which is an important feature of rural survival and closely allied to flexibility, resilience and stability is less vulnerable than an undiversified one, this is due to the likelihood of it being more sustainable over time and its ability to adapt to changing circumstances. In addition, several studies have reported a substantial and increasing share of off-farm income in total household income (Ruben and van den Berg, 2001; de Janvry and Sadoulet, 2001; Haggblade et al., 2007). Reasons for this observed income diversification include declining farm incomes and the desire to insure against agricultural production and market risks (Matsumoto et al., 2006). In other words, while some households are forced into offfarm and non-farm activities, owing to less gains and increased uncertainties associated with farming (crop and market failures), others would take up off-farm employment when returns to off-farm employment are higher or less risky than in agriculture. Mainly, households diversify into non-farm and off-farm activities in their struggle for survival and in order to improve their welfare in terms of health care, housing, sustenance, covering, etc. Thus, the importance and impact of nonagricultural activities on the welfare of rural farm households can no longer be ignored.

An understanding of the significance and nature of nonfarm and off-farm activities (especially its contribution to rural household income or resilience) is of utmost importance for policy makers in the design of potent agricultural and rural development policies. Further, the rising incidence of low level of welfare of rural households in Nigeria, that remains unabated despite various policy reforms undertaken in the country, requires a deeper understanding of the problem and the need to proffer solutions to the problem through approaches that place priority on the poor and ways on which rural households through diversification can maintain their livelihood.

\section{LITERATURE REVIEW}

In Africa, the average share of rural non-farm incomes as proportion of total rural incomes, at $42 \%$, is higher than in Latin America and higher still than in Asia (Reardon et al., 2000). Most evidence shows that rural non-farm activity in Africa is fairly evenly divided across commerce, manufacturing and services, linked directly or indirectly to local agriculture or small towns, and is largely informal rather than formal. Also, while households earn much more from rural nonfarm activity than farm wage labour, non-farm wage labour is still more important than selfemployment in the non-farm sector (Reardon, 1999; Haggblade et al., 2007). Hussein and Nelson (1998) in their study on sustainable livelihood and livelihood diversification concluded that while livelihood diversification is normal for most people in rural areas of developing countries in Africa, non-agricultural activities are critical components of the diversification process. Further, livelihood diversification is pursued for a mixture of motivations and these vary according to context: from a desire to accumulate, invest and the need to spread risk or maintain incomes, to a requirement to adapt to survive in eroding circumstances or some combination of these. In addition, the character of livelihood diversification is dependent primarily upon the context within which it is occurring (the differential access to diversification activities and the distribution of the benefits of diversification). However, the poorest rural groups probably have the fewest opportunities to diversify in a way that will lead to accumulation for investment purposes.

According to Babatunde and Quaim (2009), the pattern of income diversification among rural households in Nigeria, showed that majority of the households have fairly diversified income sources. On the average, while only $50 \%$ of the total household income is generated from farming, the rest comes from different off-farm sources. However, there are notable differences across income strata. While farming remains the dominant income source for the poorest, off-farm occupation especially self-employed activities are the main sources of income for relatively richer households. Also, Ellis (2000) using regression models, showed that households have unequal abilities to diversify their income sources and that education, asset, endowment, access to credit, and good infrastructure conditions, increase the levels of household diversification. These factors improve the opportunity to start own business and find employment in the higher paying non-farm sector.

In other words, resource-poor households in remote areas are constrained in diversifying their income sources. Ibekwe et al. (2010) using double log regression, noted that a distress diversification hypothesis is supported by the negative relationship between nonfarm income and the farm output per hectare of land in South Eastern Nigeria. They accounted for household's involvement in nonfarm activities by reference to their demographic features and to other household specific characteristics such as occupation, education level, number of spouse(s), family size and land holding as well as farm output. It could be inferred from the result that land holding size, years of workers education, per hectare value of agricultural output, occupation and age of household head are the major determinants of nonfarm income at the household level in South Eastern Nigeria. The study suggested that economic and social factors should matter in nonfarm sector policy in Southeast Nigeria if diversification is to be encouraged.

\section{MATERIALS AND METHODS}

This study was carried out in Odigbo Local Government Area of Ondo State, Nigeria. Odigbo Local Government is headquartered in 
the town of Ore town. It has an area of $1,818 \mathrm{~km}^{2}$, a population of 230,351 persons and 11 wards (NPC, 2006). The major vegetation type in the area is rainforest with a slopy topography. The area is predominantly agrarian and notable food and cash crops grown in the area include: plantain, banana, cassava, maize, yam, cocoa, oil palm and kola. The region has averagely high temperature which ranges between 21 to $29^{\circ} \mathrm{C}$ and high relative humidity with two distinct seasons namely: the rainy season which lasts from March/April to October/November and the dry season which lasts from the rest of the year October/November till March/April. Primary data used in this study were obtained in a cross-sectional survey of rural households in the study area. The collection of data involved the use of structured questionnaires to obtain information on socioeconomic and demographic characteristics such as household size, level of education, age of household heads, land holdings etc. as well as consumption expenditure, other indicators of well-being of the rural households and diversification activities of the respondents.

A multistage sampling technique was employed in selecting the representative households used for this study. The first stage was the purposive selection of Odigbo Local Government Area out of the eighteen Local Government Areas in Ondo State owing to the predominantly rural nature of the area. In the second stage, three wards out of the eleven wards in the Local Government were randomly selected while the third stage involved the selection of households based on probability proportionate to size of the households in the wards. Consequently, a random sample of 54 respondents were sampled in Oniparaga ward, 45 respondents from Ago-Alaye ward and 51 respondents from Araromi-Obu ward making a total of 150 households. However, due to incomplete questionnaire information by seven of the respondents, only information from 143 households was used for the study. These 143 households constituted the sample size used for the study. The analytical techniques employed in this study include: descriptive statistics, multinomial logistic regression and the logit regression models.

\section{Multinomial logistic regression}

When there is a dependent categorical variable, the multinomial logistic regression model is commonly used. The regressors are the same across all choices for each observation. The model is specified as:

$$
P_{r\left(Y_{i=j}\right)}=\frac{\exp \left(X_{i} \beta_{j}\right)}{\sum_{j=0}^{J} \exp \left(X_{i} \beta_{j}\right)} \quad \mathrm{j}=0----2
$$

Where $\mathrm{Yi}=3$ unordered categories of livelihood strategies adopted by the respondents: $Y 1$ = those who adopt non-farm strategy alone; Y2 = those who adopt a combination of farm and nonfarm strategies; $Y 0=$ those who adopt farm strategy alone; $Y 0$ is the reference case.

\section{Welfare measurement}

Following the adoption of Foster, Greer and Thorbecke- FGT (1984) class of poverty measures, households' total monthly expenditure was used to determine households' poverty status. The poverty line was constructed as two-thirds of the mean monthly per-capita expenditure of all households. This approach has been used by several researchers and institutions (NBS, 2005; Oni and Yusuf, 2008) as a measure of welfare. Households were then classified into their poverty status based on the poverty line:
$F G T_{\propto}=\frac{1}{N} \sum_{i=1}^{H}\left(\frac{z-y_{i}}{z}\right)^{\propto}$

Where $\mathrm{Z}$ is the poverty line; $\mathrm{N}$ is the total number of people; $\mathrm{H}$ is the number of poor who are below Z; yi is the expenditure of the ith individual; $\alpha$ is a "sensitivity" parameter which can take values between 0 and 2 .

Hence, non-poor households were those whose monthly expenditure was above or was equal to two-thirds of the mean per capita expenditure of all households while those whose per capita expenditure was below two-thirds of the mean monthly per capita expenditure were classified as poor.

\section{Logit regression model}

Logit regression analysis examines the influence of various factors on a dichotomous outcome by estimating the probability of the event's occurrence. It does this by examining the relationship between one or more independent variables and the log odds of the dichotomous outcome by calculating changes in the log odds of the dependent as opposed to the dependent variable itself. The log odds ratio is the ratio of two odds and it is a summary measure of the relationship between two variables (Olayemi et al., 1995). The Logit model is presented as:

$\mathrm{P}=\frac{\exp (z)}{1+\exp (z)}$

Where $\mathrm{P}$ is the proportion of occurrence.

$Z=\beta_{0}+\beta_{1} X_{1}+\ldots \ldots .+\beta_{n} X_{n}$

Where $X_{1} \ldots . . X_{n}$ are the explanatory variables. The inverse relation of Equation 1 is:

$\left.Z=\ln \frac{p}{1-P}\right)$

That is, the natural logarithm of the odds ratio, known as the logit. It transforms $P$ which is restricted to the range $[0,1]$ to a range $[-\infty$, $\infty]$.

$\mathrm{Y}=$ Poverty status of households (Poor $=1,0$ otherwise).

The independent variables include:

$X_{1}=$ Age of the respondents (in years);

$\mathrm{X}_{2}=$ Gender of household head (male $=1,0$ if otherwise);

$\mathrm{X}_{3}=$ Primary education (yes $=1,0$ if otherwise);

$\mathrm{X}_{4}=$ Secondary education (yes $=1,0$ if otherwise);

$\mathrm{X}_{5}=$ Tertiary education (yes $=1,0$ if otherwise);

$\mathrm{X}_{6}=$ Primary occupation of household head (farming $=1,0$ if otherwise);

$X_{7}=$ Own house (yes $=1,0$ if otherwise);

$\mathrm{X}_{8}=$ Household size;

$X_{9}=$ Marital status (married $=1,0$ if otherwise);

$\mathrm{X}_{10}=$ Total household income ( $)$.

\section{RESULTS AND DISCUSSION}

Table 1 presents the socio-economic characteristics of 
Table 1. Socio- economic characteristics of the respondents.

\begin{tabular}{|c|c|c|}
\hline Variable & Frequency & Percentage \\
\hline \multicolumn{3}{|l|}{ Age } \\
\hline $20-39$ & 36 & 25.2 \\
\hline $40-59$ & 79 & 55.2 \\
\hline$\geq 60$ & 28 & 19.6 \\
\hline \multicolumn{3}{|l|}{ Sex } \\
\hline Male & 121 & 84.6 \\
\hline Female & 22 & 15.4 \\
\hline \multicolumn{3}{|l|}{ Marital status } \\
\hline Single & 6 & 4.2 \\
\hline Married & 117 & 81.8 \\
\hline Seperated/divorced & 7 & 4.9 \\
\hline Widowed & 13 & 9.1 \\
\hline \multicolumn{3}{|l|}{ Household size } \\
\hline $1-6$ & 86 & 60.1 \\
\hline $7-12$ & 55 & 38.5 \\
\hline$>13$ & 2 & 1.4 \\
\hline \multicolumn{3}{|l|}{ Educational status } \\
\hline No formal education (NFE) & 23 & 16.1 \\
\hline Primary & 55 & 38.5 \\
\hline Secondary & 42 & 29.4 \\
\hline Tertiary & 23 & 16.0 \\
\hline \multicolumn{3}{|l|}{ Primary occupation } \\
\hline Farming & 79 & 55.2 \\
\hline Artisan & 16 & 11.2 \\
\hline Trading & 31 & 21.7 \\
\hline Govt. salaried Job & 17 & 11.9 \\
\hline \multicolumn{3}{|l|}{ Type of livelihood strategy } \\
\hline \multicolumn{3}{|l|}{ Strategy adopted } \\
\hline Farm only & 10 & 7.0 \\
\hline Non farm only & 28 & 19.6 \\
\hline Farm and non farm & 105 & 73.4 \\
\hline \multicolumn{3}{|l|}{ Monthly income (N) } \\
\hline $11,000-30,000$ & 50 & 35.0 \\
\hline $31,000-50,000$ & 56 & 39.2 \\
\hline $51,000-70,000$ & 18 & 12.6 \\
\hline$>70,000$ & 19 & 13.2 \\
\hline Total & 143 & 100.0 \\
\hline
\end{tabular}

Source: Field survey (2012).

the respondents. Results revealed that more than fourfifths $(84.6 \%)$ of the households were headed by males while more than half $(55.3 \%)$ of the respondents were in their economic active age. The average age of the respondents stood at $47.5 \pm 11.9$ years in the study area. While married household heads were in the majority $(81.8 \%)$ in the study area, about three-fifths of the respondents had household sizes of between 1 and 6 
Table 2. Reasons for diversification.

\begin{tabular}{lcc}
\hline Reason for diversification & Frequency & Percentage \\
\hline Limited agricultural income & 7 & 4.9 \\
Large family & 2 & 1.4 \\
Availability of nonfarm opportunities & 3 & 2.1 \\
Seasonal nature of agric produce & 3 & 2.1 \\
Favourable demand for goods and services & 7 & 4.9 \\
To live well & 11 & 7.7 \\
Limited agricultural income and large family & 67 & 46.9 \\
Limited agricultural income, large family and availability of non farm opportunities & 20 & 14.0 \\
Seasonal nature of agric produce and availability of non-farm opportunities & 23 & 16.0 \\
\hline
\end{tabular}

Source: Field survey (2012).

Table 3. Factors influencing the choice of livelihood strategy adopted.

\begin{tabular}{lcccc}
\hline \multirow{2}{*}{ Variable } & \multicolumn{2}{c}{ Nonfarm } & \multicolumn{2}{c}{ Combination of farm and nonfarm } \\
\cline { 2 - 5 } & $\mathbf{d y} / \mathbf{d x}$ & $\mathbf{Z}$ & $\mathbf{d y} / \mathbf{d x}$ & $\mathbf{Z}$ \\
\hline Gender & 14.10 & 0.01 & 12.63 & 0.01 \\
Age & -0.057 & -1.07 & -0.001 & -0.02 \\
Household size & 0.89 & $2.92^{\star}$ & 0.65 & $2.53^{\star}$ \\
Total income & 0.07 & $2.11^{\star \star}$ & 0.001 & $1.86^{\star \star *}$ \\
Own house & 0.26 & 0.18 & 0.13 & 0.09 \\
Married & -14.20 & -0.01 & -14.04 & -0.01 \\
Primary education & -2.55 & $-1.79^{\star \star \star}$ & -1.74 & $-1.70^{\star \star \star}$ \\
Secondary education & 14.97 & 0.01 & 14.81 & 0.01 \\
Tertiary education & -1.66 & -0.84 & -2.16 & -1.26 \\
\hline
\end{tabular}

Source: Field survey (2012). ${ }^{*}$ significant at $1 \%,{ }^{* *}$ significant at $5 \%$, ${ }^{* * *}$ significant at $10 \%$. Number of observation $=$ 143. $\operatorname{LR}$ chi $^{2}(18)=59.58$. Prob $>\mathrm{chi}^{2}=0.0000$. Log likelihood $=-73.056464$., Pseudo $R^{2}=0.2896$.

members. The average household size stood at $6.1 \pm 2.6$ in the study area. With respect to the educational status of the respondents, almost two-fifths of the respondents had primary education while only 16.1 had no formal education. This implies that most of the respondents have one form of formal education or the other. Highlights of the occupational analysis of the respondents revealed that more than half of the respondents were engaged in farming as their primary occupation, indicating that farming is the predominant occupation in the study area. This is expected as most households in the rural areas depend mainly on agriculture as their primary source of livelihood. However, literature has shown that diverse income portfolio, creates more income and distributes income more evenly. Thus, it is easier to adopt the combined livelihood strategies than switching full time between either of them (Ellis, 2000). In line with this, as shown in the table, very few of the respondents obtained income from only one source as almost three-quarters of the household heads engaged in a combination of farm and nonfarm activities. With respect to the monthly income distribution of the respondents, more than half of the respondents earn between $\$ 31,000$ and $\$ 70,000$ monthly while a little above one-tenth of the sampled respondents earn over $\$ 70,000$ per month. The average monthly income of the respondents in the study area stood at $\$ 46,533 \pm 24,315$.

As presented in Table 2, most of the respondents had various reasons for diversifying into other activities. Some of these reasons include limited agricultural income, large family size, availability of non-farm opportunities, seasonal nature of agricultural produce, favourable demand for goods and services or a combination of these, among others. However, the main reason for diversification reported by almost half of the respondents in the study area was a combination of limited agricultural income and large family size.

The result of the multinomial regression analysis of the factors influencing the choice of livelihood strategies adopted by the respondents in Odigbo Local Government of Ondo state is presented in Table 3 . The chi-square value of 59.58 which was significant at $1 \%$ level shows that the model has a good fit for the data. The marginal effects result of the regression is reported as follows. 
Table 4. Poverty status of households.

\begin{tabular}{lcc}
\hline Poverty status & Frequency & Percentage \\
\hline Non-poor & 82 & 57.3 \\
Poor & 61 & 42.7 \\
Total & 143 & 100.00 \\
\hline
\end{tabular}

Source: Field survey (2012).

The coefficient of household size of 0.89 was significant at $1 \%$, implying that an increase in the household size by one member increased the likelihood of adopting the only non-farm strategy by 0.89 relative to the adoption of the only farm strategy. That is, the larger the household size, the higher the likelihood of opting for the only non-farm livelihood strategy. This result is inconsonance with the findings of Harjes (2007), in which increase in household size increased the likelihood of adopting nonfarm activities. Similarly, the coefficient of total income of household of 0.07 was positive and significant, implying that a naira increase in total household income increased the likelihood of adopting the only non-farm strategy relative to the only farm strategy.

This may be owing to the fact that nonfarm activities give higher returns in terms of income. This finding corroborates the findings of Babatunde and Qaim (2009). On the other hand, the coefficient of primary education was negative (-2.55) and significant indicating that household heads with primary education are less likely to adopt the only non-farm strategy relative to the only farm strategy where they are likely to have better prospects. This result is supported by the findings of Norsida and Sadiya (2009) that individuals who have more years of schooling have a higher likelihood of participating in nonfarm work. In other words, the higher the level of education, the higher the likelihood of participation in non-farm activities.

With respect to the choice of the combination of farm and non-farm strategy as a livelihood option, the coefficients of household size and total household income were positive and significant suggesting that a member increase in the household size and a naira increase in total household income increased the likelihood of adopting a combination of farm and nonfarm strategy. This could be owing to the fact that in large sized households, limited resources are spread thinly on maintaining a large number of people in terms of meeting their basic and other needs and the fact that increased household size is also synonymous with more dependants who do not contribute to household income. Thus, households in order to augment household income for meeting the basic needs of the family will engage in a combination of farm and non-farm strategy relative to the choice of the farm strategy only. This result corroborates the findings of Babatunde and Qaim (2009) and Ellis (2000).

On the other hand, the coefficient of primary education was negative and significant implying that household heads with primary education are less likely to adopt a combination of farm and nonfarm strategy. From these findings, it is evident that the major factors influencing the choice of livelihood strategy adopted in Odigbo Local Government area of Ondo State are household size, total household income and primary education of the household head. Per-capita expenditure was used as a proxy for welfare in this study. Based on this, the poverty line constructed as two-thirds of the mean per-capita expenditure of all the households stood at $\$ 2,752.03$. This implies that households whose per capita expenditure fall below 2,752.03 were classified as poor while households whose per capita expenditure equaled or was above the poverty line were classified as nonpoor.

Based on the poverty line, households were classified into their poverty status as either non-poor or poor as presented in Table 4 . The table shows that $42.7 \%$ of households in Odigbo local government area of Ondo state are poor while $57.3 \%$ are non-poor. Table 5 presents the effect of livelihood diversification as well as other socio-economic factors that influence rural households' welfare in Odigbo Local Government area of Ondo State. The 'chi square' value of 107.35 which was significant at $1 \%$ indicates that the model has a good fit. The results of the marginal effects after Logit are reported as follows:

The coefficient of gender was negative and significant implying that households headed by males have a lower level of welfare than their female counterparts. Specifically, being a male headed household increased the likelihood of being poor by 0.313 . Similarly, the coefficient of secondary education was negative implying that household heads with secondary education have a lower likelihood of being poor relative to those with no formal education. On the other hand, the coefficient of household size was positive indicating that a member increase in household size increased the likelihood of being poor by 0.132 . This could be as a result of greater burden on the actively working members of the household.

While the coefficient of the use of firewood as a source of energy for cooking was positive, the coefficient of living in a flat/apartment was negative. This implies that households using firewood as a source of energy for cooking have a higher likelihood of being poor, while households living in a flat/apartment have a lower likelihood of being poor. These are reflections of the level of welfare of the households as these variables are usually determined by the level of income of such households. Income from non-farm activities as well as income from a combination of non-farm and farming activities, impacted welfare positively relative to income 
Table 5. Effect of livelihood diversification on household welfare.

\begin{tabular}{lccc}
\hline Variable & dy/dx & Coefficient & Z \\
\hline Gender & -0.313 & -3.546 & $-2.34^{\star \star}$ \\
Age & -0.086 & -0.050 & -1.54 \\
Household size & 0.132 & 0.772 & $3.56^{\star}$ \\
Married & -0.295 & -1.424 & -0.57 \\
Primary education of HH & -0.209 & -1.393 & -1.30 \\
Secondary education of HH & -0.287 & -1.997 & $-1.74^{\star \star *}$ \\
Tertiary education of HH & -0.149 & -1.087 & -0.86 \\
Firewood & 0.355 & 2.577 & $3.23^{\star}$ \\
Own house & 0.127 & 0.836 & 1.24 \\
Protective well & -0.100 & -0.563 & -0.86 \\
Flat/apartment & -0.215 & -1.351 & $-2.01^{\star *}$ \\
Non farm income & -0.036 & -3.299 & $-4.52^{*}$ \\
Farm + non-farm income & -0.411 & -2.501 & $-3.09^{*}$ \\
\hline
\end{tabular}

Source: Field survey (2012). *Significant at $1 \%,{ }^{* *}$ significant at $5 \%,{ }^{* * *}$ significant at $10 \%$. Number of observation $=143$. LR $\operatorname{chi}^{2}(14)=107.35$. Prob $>\mathrm{chi}^{2}=0.0000$. Log likelihood $=-43.897308$. Pseudo $R^{2}=0.5501$.

from farming activities only. This is expected as agriculture in the rural areas of Nigeria is largely characterized by low capital involvement, use of crude implements, poor infrastructural and storage facilities and human drudgery which ultimately leads to lower average earnings. Hence, nonfarm activities and a combination of farm and non-farm activities were pursued as strategies to increase household welfare in the study area.

\section{CONCLUSION AND RECOMMENDATIONS}

This study has shown that non-farm income plays a very important role in augmenting farm-income as almost three-quarters of the respondents adopted a combination of farm and nonfarm strategy. This is an indication that farming alone is not an adequate source of revenue for the rural households. Therefore, promoting non-farm employment may be a good strategy for supplementing the income of farmers as well as sustaining equitable rural growth. This could be achieved through training programmes directed towards training farmers in skills that can be used in non-farm jobs in their vicinity as well as improvements in infrastructure, education and financial markets.

Specifically, engagement in non-farm activities, apart from reducing income uncertainties and providing a source of liquidity in areas where credit is constrained, could increase agricultural productivity as it provides the resources necessary for investment in advanced agricultural technologies. The adoption of better technology is expected to be highly profitable and will encourage the transition from traditional to modern agriculture. Therefore, there is a need for the government to formulate policies to increase the availability of non- farm jobs in the rural areas. Further, the private sector should be encouraged to create income-generating activities in the rural areas to enhance their livelihood diversification activities and ultimately their living standard.

\section{REFERENCES}

Babatunde RO, Qaim M (2009). The role of off-farm income diversification in rural nigeria: driving forces and household access. Conference paper presented on 23 mar 2009 at the Centre for the Study of African Economies (CSAE), Economics Department, Oxford. http /conferences/2009-EDiA/papers/051-Babatunde.pdf-[28/02/10].

Barrett CB, Reardon T, Webb P (2001). "Nonfarm income diversification and household livelihood strategies in rural Africa: concepts, dynamics and policy implications, Food Pol. 26:315-331.

De Janvry A, Sadoulet E (2001). Income strategies among rural households in mexico. The role of off- farm activities. W. Dev. 29(3):467-480.

Ellis $F$ (2000). The determinants of rural livelihood diversification in developing countries. J. Agric. Econ. 51(2):289-302.

Foster J, Greer J, Thorbecke E (1984). A Class of Decomposible Poverty Measures. Econometrica 2(81):761-766.

Gordon A, Craig C (2001). Rural non-farm activities and poverty alleviation in sub-Saharan Africa." Social and economic development department. Natural Resources Institute. Policy Series. P. 14.

Haggblade S, Hazell P, Reardon T (2007). Transforming the rural nonfarm economy. John Hopkins University Press Baltimore.

Harjes T (2007). Globalization and income inequality: An European perspective," IMF Working Paper 07/169 (Washington: International Monetary Fund).

Hussein K, Nelson J (1998). Sustainable livelihoods and livelihood diversification, IDS working, Brighton: Institute of development studies. P. 69.

Ibekwe UC, Eze CC, Ohajianya DO, Orebiyi JS, Onyemauwa CS, Korie OC (2010). Determinants of nonfarm income among farm households in South East Nigeria. Acad. Ari. 2(8):29-33.

Matsumoto T, Kijima Y Yamano T ( 2006). The role of local nonfarm activities and migration in reducing poverty: evidence from Ethiopia, Kenya, and Uganda. Agric. Econ. 35:449-458.

National Population Commission (2006). National Census Report. 
NBS (2005). Annual Needs and Livelihood Assessment. Millenium Development Goals Brochure, South Sudan.

Norsida M, Sadiya SI (2009). Off-farm employment participation among paddy farmers in the Muda Agricultural Development Authority and Kemasin Semerak granary areas of Malaysia" Asia-Pacific Dev. J. 16(2):141-153.

Olayemi JK (1995). A Survey of Approaches to Poverty Alleviation. A Paper presented at the NCEMA National Workshop on Integration of Poverty Alleviation Strategies into Plans and Programmes in Nigeria Ibadan, 27 November- 1 December.

Oni OA, Yusuf SA (2008). Determinants of Expected Poverty among Rural Households in Nigeria. AERC Research Report 183, September.
Reardon T (1999). Rural non-farm income in developing countries. Rome: Food and Agriculture Organization.

Reardon T, Taylor JE, Stamoulis K, Lanjouw P, Balisacan A (2000). Effects of nonfarm employment on rural income inequality in developing countries: An investment perspective. J. Agric. Econ. 51(2):266-288.

Ruben R, Van den Berg M (2001). Non farm employment and poverty alleviation of rural households in Honduras. World Develop. 29(3):549-560.

Yusuf SA, Oni OA (2008). Expected poverty profile among rural households in Nigeria. Afr. J. Econ. Pol. 15(1):139-163 